\title{
Global Collective Intelligence in Technological Societies: as a result of Collaborative Knowledge in combination with Artificial Intelligence
}

\author{
Juan Carlos Piedra Calderón, J. Javier Rainer \\ Universidad Pontificia de Salamanca, Spain
}

\begin{abstract}
The big influence of Information and Communication Technologies (ICT), especially in area of construction of Technological Societies has generated big social changes. That is visible in the way of relating to people in different environments. These changes have the possibility to expand the frontiers of knowledge through sharing and cooperation. That has meaning the inherently creation of a new form of Collaborative Knowledge. The potential of this Collaborative Knowledge has been given through ICT in combination with Artificial Intelligence processes, from where is obtained a Collective Knowledge. When this kind of knowledge is shared, it gives the place to the Global Collective Intelligence.
\end{abstract}

Keywords - Collective intelligence, knowledge managenemt, artificial intelligence, intelligent systems, collaborative multimedia, ICT.

\section{INTRODUCTION}

$\mathrm{T}$ The inclusion of the Technology in normal live has meaning big changes in society. If ones can see to the past through ICT, in one minute could see: more than eleven millions of sending instant messages, more than fifty eight shopping web transaction, more than twenty thousand app downloads for mobile, more than six hundred and fifty new smartphone functioning, more than twenty four hours in video are uploaded in YouTube, more than three thousand tweets are sending, more than two millions searches in google and many more [1].

The use of ICT has been the key factor through the use of information and knowledge has introduced to society in the way to conform part of the Technological Societies. In fact, the European and Information Global Society report [2], talks about how new technologies, telecommunication and information has made an important global revolution which is comparable or even superior to the industrial revolution. In this new revolution, knowledge is recognizing as a technical factor that has made transformations in social, economic, political and institutional dimension.
As a result of this technological revolution and the network telecommunication advances has created a necessity to introduce new concepts and processes. The most important are collaboration, cooperation and sharing information and knowledge with the objective to give them an added value through acquisition, absorption, processing and communication of these elements [3]. This encouraged the introduction of two growth technical and economic factors which are innovation and investigation. That when both are enriched by continuous learning processes and once led to a global society forms a Collective Intelligence.

This concept is also directly linked to some dimensions of human development, such as: social, cultural, economic, political, technological and environmental. That produces institutional and plural perspectives changes in development of dynamism of the global society changes [4]. In fact, members of countries in the World Summit of Information Society ${ }^{9}$ emphasize that the most important thing to consider is the commitment and desire to build a people-center society, focused in a global technological integration with an orientation to help and to a sustainable develop. Being important creation, search, use, and sharing of information and knowledge, creating a mutual participation on communities and people to help improve the quality of life [4].

\section{DIGITAL AND COLLABORATIVE LEARNING}

Every knowledge form inside Technological Societies in combination with the trend to collaborate and to share, shows learning as an important factor in the assimilation and transmission of an improved knowledge taking from information and knowledge received. Digital and Collaborative learning is superior than traditional learning in the way that a person can access and learn better from his own contents and the other people that share their more specific information and knowledge [5].

This create a sense of global collaborative learning where everyone has the same level to learn and to access to information in every place in the world, that means for example that an African young can access to the same 
knowledge that other young that is studying in the best university [6]. People from more collaborative environments learn more complex technological abilities with great facility and familiarity [7]. For this reason educative model built through more collaborative environments help to develop more creativity and potential in people which are growing up in more technicians environments [8][9].

This fundamental role of ICT in this new form of learning is based in a tendency toward "learning to learn" [10], that through adaptive methods and a greater appreciation of knowledge and collaboration between individuals [11]. It will be of great contribution to be transmitted, shared and especially compared to other thoughts, scientists and with Artificial Intelligence systems that process natural language, in the way to generate true global solution shared. These gradually improve the perception of complexity (in positive sense) of life in this Technological society.

One way to donate potential to this kind of collaborative learning is through the use of methodologies that strategically combine traditional learning techniques with new learning techniques based in new knowledge creation through Artificial Intelligence technics as intelligence tutorial systems that do processes allowing form an own strategy and molds as other Artificial Intelligence systems to learning needs. Being this interaction very propitious to conform the collaborative learning [12].

\section{COllabORATIVE KNOWLEDGE}

There is no doubt that the best promoter of collaborative knowledge has been telecommunications networks. What at first had a useful of interchange and interconnection finally has being a space where collaboration between users and intelligent systems has become in a growing and daily trend. This is because adaptive learning of Artificial Intelligence through machine learning systems join with human learning has created a new model of collaborative learning based in cooperation between individual and devices [13], which helps to acquire and to build new knowledge giving potential development of new technologies and that helps to build a new collaborative knowledge.

At an organizational level this vision of a collaborative society allows the development of new knowledge in groups that function as knowledge production networks, which allows the creation of methodologies that encourage cooperative working form, assuming responsibility on self-learning and in knowledge transmission [14]. Thanks to connectivity this network society is itself a communication system globalized that have the capacity to join people from different cultures and languages through one and unique technological architecture [15].

Many tools used in this moment have been designed in a collaborative way, which aided by Artificial Intelligence processes such as intelligence systems, expert systems and recognition systems, based in knowledge engineering technics, obtaining a new assessment and dimension of this collaborative knowledge that is capable to increase technology experience [16]. Many of these tools have taken the development to a new way of perception of the new Semantic Web environment and App giving a way to the new construction of Cloud computing.

TABLE I

TRANSMISSION TYPE OF KNOWLEDGE

\begin{tabular}{cc}
\hline \hline TRANSMISSION TYPE OF KNOWLEDGE \\
\hline Knowledge element & Transmission Type \\
\hline Individual Knowledge & One way \\
Collaborative Knowledge & Biderectional \\
Collective Knowledge & Bidirectonal \\
Cloud Contribution & One way \\
AI Contribution & Bidirectional \\
\hline \hline
\end{tabular}

The thought called "knowledge paradox" says that according more knowledge is developed, it will lose its current value, therefore, it will be necessary creating new concepts such as technological wisdom. That means every new concept will be related with concepts in the ICT age based in a collective wisdom, and will be used to the growth of society [17], follow the way to the global technical revolution.

\section{COLLECTIVE KNOWLEDGE}

This technological age is expanding through combination of social, human and technological factors. Mainly through two purely intellectual processes: knowledge and intelligence. Where collaboration and cooperation in large scale, in union with interconnection that allows the interchange of these intellectual elements, conform a global network of knowledge, that are concentrate in form as a greater knowledge inside the global brain where the thought of every person works as a neuron and the synapses accurse through Artificial Intelligences technics as Bayesian networking and fuzzy logic, directly on the Cloud.

A scientific study of the Technical Institute of Massachusetts in EEUU, says that the more efficient work is "group work". That is because collective knowledge involves flexibility in allocating activities, and individual and group participation to give solution to problems. These allows the creation of a sensitivity social dynamic among team members. The result of these dynamics shows the existence of a collective intelligence as a joint ability, which is defined by the same ability of the individual intelligence and his relations with others [18].

This does not mean the discovery of collective knowledge concept, because it have already been used for long time in teams, however, is in the technological age, thanks to the Artificial Intelligence systems and ICT when it really started to have a real and potential meaning. Being the potential of this collective intelligence the creation of new knowledge networks [18], where an important element is the complexity that has arrived these knowledge networks as a collaborative system that interconnects equal intelligence and are implicated with sharing and developing of the new knowledge. This has changed the way to work in three types of knowledge 
networks: investigation, business and education [13].
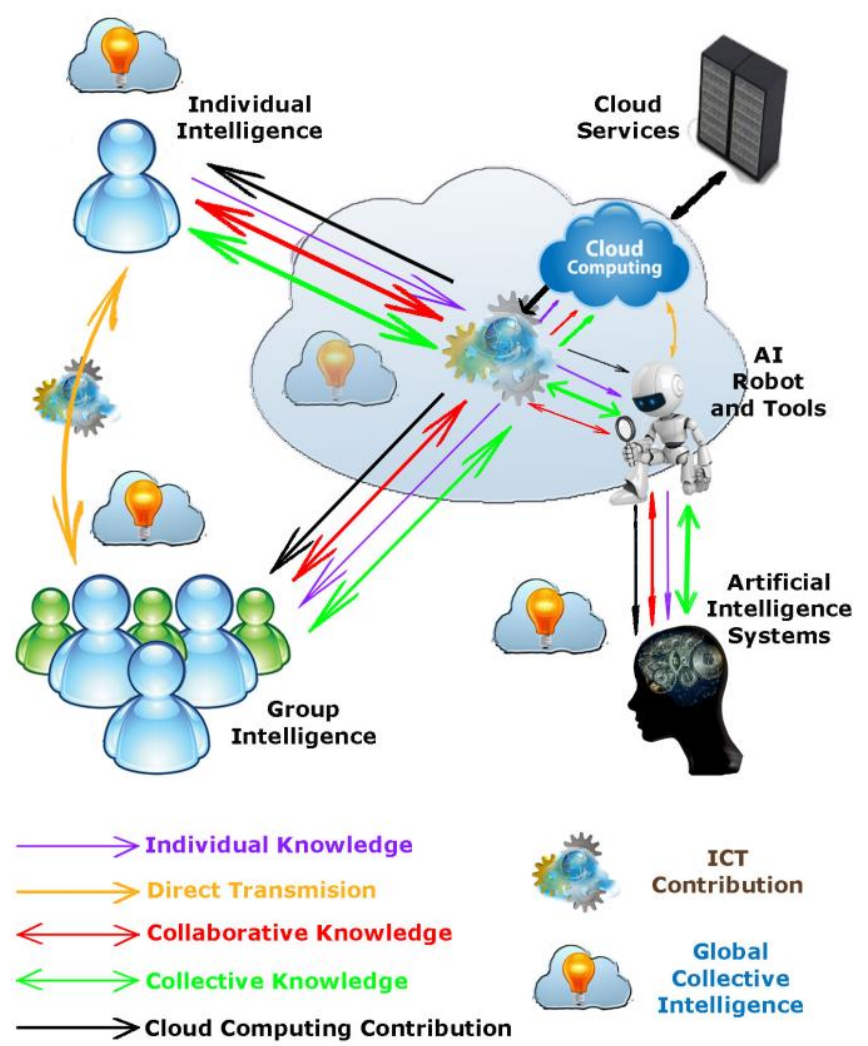

Fig. 1. Global Collective Intelligence.

Until few years ago, wisdom was concentrated and represented just by lone geniuses, but now it is represented and performed by collaborating people which sharing their knowledge arrive to an enriched knowledge that generated collective intelligence. That does not mean that there is no longer talented people and geniuses, but ICT evolution allows global participation creates the possibility of new developments, in short term, through this new technical-social element, as is global collective intelligence, which allows the creation of global and community wisdom [17].

All of these have transform human mindset from individual thinking to global thinking [20] which allows build a new intellectual level called global collective intelligence. These new kind of collective intelligence is giving by the direct relationship between normal collective knowledge processes with aids of Artificial Intelligence systems, in addition to ICT technologies [31].

\section{V.ARTIFICIAL INTELLIGENCE CONTRIBUTION}

Artificial Intelligence has been presented as a desire to get a better comprehension of human behavior through multidisciplinary information processes that involves complex aspects of own people cognitions and social processes that lead to acquire knowledge through collaborative processes [21]. Also the desire of imitate cognitive human behavior has made that in this half of century of application of Artificial
Intelligence, it has passed from simple theories and assumptions to have intelligent systems that follow algorithms created from logical models. Which with the help of different engineering techniques increasing the resemblance of the complex human thought.

Inside of ICT field, Artificial Intelligence has contributed significantly in last years in conformation and concretion of virtualization tools that give a delocalization service in real time. For this it has become very popular the use of Cloud Computing [22], which allows to cover the necessities of software and web services demand through the Cloud, in a bigger scale and lower cost that invest in an own technical infrastructure.

The creation of a collaborative platform can helps to collective absorption of the risk and a greater flexibility to give effectively solutions to the market [23]. Cloud Computing has allowed developing of a digital economy, which has allowed organization to obtain a key element over global economy. This is to increase the competitiveness and other benefits as: improve demand attention on infrastructure and services, stimulating activity and guarantee sustainability, process optimization, creating new market opportunities, business stability, and return of investment, among others [24].

The interaction between business, society and Technology though the creation, use and storage of large amounts of multimedia information inside the Big Global Data ${ }^{10}$, which will need more and more sophisticated Artificial Intelligence Systems and equipped with operational intelligence and data mining, which help to have a faster and personalized access to all information helped by knowledge engineering [25]. And likewise through intelligent agents it is possible to learn to recognize patterns to obtain suggestions from access information systems [26], which help to increase in collaborative knowledge and the growth in collective intelligence.

\section{TABLE II}

ARTIFICIAL INTELLIGENCE SYSTEMS THAT CONTRIBUTE TO THE CREATION OF GLOBAL COLLECTIVE KNOWLEDGE

\begin{tabular}{cc}
\hline \hline AI System & Field \\
\hline Machine Learning & Automatic Learning \\
Tutorial Systems & Learning Help \\
Knowledge Engineering & Expert Systems Develop \\
Bayesian Networks & Networking Assignation \\
Computational Linguistic & Voice Recognizing \\
Natural language Processing & Communication \\
Data Mining & Data Exploration \\
Software Agents & Information Treatment \\
Fuzzy Logic & Decision-making \\
Operational Intelligence & Real Time Information \\
& Management \\
\hline \hline
\end{tabular}

VI. COLlaborative Multimedia IMPORTANCE

In the past years, the arrival of mature has had both Cloud Computing and Smartphone technologies have had a big

10Big Global Data is a concept of a large global database. 
influence in society. Which allowed to introduce agile changes enhanced by the large interconnection between people and technologies [27]. The combination of digital social media with the set of Artificial Intelligence techniques as a computational linguistic and natural languages processing, integrated in digital devices and app with transmission and communication networks have changed the way that people socialize. Relationships include a new compromise concept in communication [28], reflecting a better communication, comprehension quality and optimizing knowledge exchange [29].

Maybe it is here, where more Artificial Intelligence techniques as a software agents have been used to process all collaborative knowledge given by multimedia through tools as robots applied to the Cloud, expert and predictive tools that attempt to predict knowledge preferences, which joined with patterns recognized tools can suggest the best information options obtaining a more dynamic knowledge [30]. This helps to grow in a more Collaborative Multimedia experience that becomes more and more in a collective knowledge storage tool from which it is possible to learn in a global and collaborative way.

\section{CONCLUSION}

The contribution received by the human elements as knowledge and intelligence, that have been maximize by ICT and their big influence in Technological Societies have begun to transcend human frontiers. The emergence and maturation of Artificial Intelligence has made human individual and collective cognitive elements creates and improves a new enriched knowledge. Which when it can be shared through communication network and processed by collaborative tools, generates an individual intelligence.

This individual intelligence sharing with others and transmitted as a Collaborative Knowledge and also process by Artificial Intelligence tools form a new Collective Intelligence that thanks to telecommunication networks becomes into a Global Collective Intelligence.

\section{REFERENCES}

[1] Ericsson. (2011). Networked Society - Shaping Ideas [Online]. Ericsson Channel. Available: http://www.youtube.com/watch?NR=1\&v=tHoh2ilSQs\&feature=endscreen. [03/12/12]

[2] European Commission. (1994). Europe and the Global Information Society [Online]. Report of European Commission. Luxemburg. pp. 5 40.

Available: http://aei.pitt.edu/1199/1/info_society_bangeman_report.pdf. [30/09/13]

[3] Lévy, P. (2004). Inteligencia Colectiva: Por una Antropología del Ciberespacio [Online]. Traducción por Organización Panamericana de la Salud. Available: http://inteligenciacolectiva.bvsalud.org/public/documents/pdf/es/intelige nciaColectiva.pdf. [30/09/13]

[4] Torres, R M. (2005). Sociedad De La Información / Sociedad Del Conocimiento [Online]. Universidad de Barcelona. pp. 1 - 3. Available:

http://www.ub.edu/prometheus21/articulos/obsciberprome/socinfsoccon .pdf. [27/12/12]

[5] Cisco. (2012). Collaborative Learning Inside the Classroom [Online]. Cisco
http://www.youtube.com/watch?v=gaLzoc3MhG0. [10/12/12]

[6] Ericsson. (2012). Learning \& education - the future of learning [Online]. Portal Web Available: Ericsson. http://www.ericsson.com/thinkingahead/networked_society/learning_ed ucation. [10/12/12]

[7] Vázquez N. \& Alonso V. \& Sernández A. \& Santos M \& Rodrigo C. (2011). Replicación de Sistemas Virtualizados para la aplicación de Servivios en un Entorno Virtual Multiusuario en la UNED [Online]. Revista Boletín de la Red Nacional de I+D RedIRIS. N ${ }^{\circ}$ 90. pp. 55 - 62. Available:

http://www.rediris.es/difusion/publicaciones/boletin/90/ponencia8.B.pdf . [30/09/13]

[8] Ericsson. (2010). A Vision Of A 2015 Multimedia Experience [Online]. Ericsson Channel. Available: http://www.youtube.com/watch?feature=endscreen $\& N R=1 \& v=u J p r-$ dpLm8w. [01/12/12]

[9] Ericsson. (2011a). Get ready to join the ride towards a networked society! [Online]. Ericsson Channel. Available: http://www.youtube.com/watch?v=_aET8-JTRI. [12/12/12]

[10] Coursera. (2012). E-Learning And Digital Cultures [Online]. Portal Web de Coursera. Sección Courses. Available: https://www.coursera.org/course/edc. [19/12/12]

[11] Piattini V, M. (2009). Pasado, Presente y Futuro de la Fabricación de Software. Lección inaugural del solemne acto de apertura del curso 2009/2010 de la Universidad de Castilla - La Mancha. pp. 5 - 38.

[12] Urrietavizcaya L, M. (2001). Sistemas Inteligentes en el ámbito de la Educación [Online]. Revista Iberoamericana de Inteligencia Artificial. Vol 5. $\quad \mathrm{N}^{\mathrm{o}}$ 12. ISSN-e: 1988-3064. Available: http://cabrillo.lsi.uned.es:8080/aepia/Uploads/12/132.pdf. [30/09/13]

[13] Valentín L-, Carrasco A, Konya K, Burgos D. (2013). Emerging Technologies Landscape on Education. A review. International Journal of Interactive Multimedia and Artificial Intelligenece (IJIMAI).Vol.2 Special Issue on Improvements in Information Systems and Technologies pp. 55-70. DOI: 10.9781/ijimai.2013.238.

[14] Moreno C, M. (2005). Comunidades de la Sociedad del Aprendizaje [Online]. Universidad de Guadalajara. pp. 3 - 6. Available: http://mail.udgvirtual.udg.mx/biblioteca/bitstream/123456789/180/1/X EI-Comunidades.pdf. [14/01/13]

[15] Castells, M. \& Cardoso, G. (2005). The Network Society From Knowledge to Policy. Center for Transatlantic Relations. Washington, DC. pp. $3-5$.

[16] García F, R. (2008). Sistemas Basados en Tecnologías del Conocimiento para Entornos de Servicios Web Semánticos [Online]. Tesis Doctoral. Universidad de Murcia. pp. 50 - 90. Available: http://hdl.handle.net/10201/154. [30/09/13]

[17] Tasaka, H. (2009). La paradoja de la sociedad del conocimiento [Online]. Entrevista en Infonomiatv. Available: http://www.youtube.com/watch?v=FzbO8NdD86g. [23/12/12]

[18] Malone, T W. (2010). Collective Intelligence [Online]. MITNewsOffice Channel. Available: http://www.tendencias21.net/Demostrada-la-existencia-de-lainteligencia-colectiva_a4929.html. [06/01/13]

[19] Turiera, T. (2007). Conversando Con Hiroshi Tasaki [Online]. Portal Web Infonomia. http://www.infonomia.com/if/articulo.php?id=111\&if=54. [08/01/2013]

[20] Sánchez B, J M. (2011). La Era De La Infancia: Una Nueva Ética Del Futuro [Online]. Web La infancia y la Sociedad del Conocimiento. Available: http://infanciasociedadconocimiento.blogspot.fr/2011/11/laera-de-la-infancia-una-nueva-etica.html. [09/01/13]

[21] Escolano R, F. \& Cazorla Q, M A. \& Alfonso G, M I. \& Colomina P, O. \& Lozano O, M A. (2003). Inteligencia Artificial: Modelos, Técnicas y Áreas de Aplicación. Homson Ediciones Spain. Parainfo S.A. pp. Prólogo, 1 - 7. ISBN: 84-9732-183-9.

[22] Buckley, D. \& Kaliski, B. \& O’Sullivan, B. \&. Artificial Intelligence for Data Center management and Cloud Computing. AAAI Workshop Journal. pp. 44. ISBN: 978-1-57735-524-11-08.

[23] Oxford Economics. (2011). The New Digital Economy - How It Will Transform Business [Online]. Oxford Economics, At\&T, PwC, Cisco, Citi, $\quad$ Sap. $\quad$ pp. $\quad 5 \quad-\quad$ 8. $\quad$ Available: http://www.pwc.com/gx/en/technology/publications/assets/the-newdigital-economy.pdf. [16/03/13]

[24] Cámara de Comercio España. (2012). SPAIN 2020: La Economía 
International Journal of Artificial Intelligence and Interactive Multimedia, Vol. 2, $N^{o} 4$.

Digital, Clave Para Retomar El Crecimiento [Online]. Cámara de Comercio de EE en España. Available: http://www.amchamspain.com/sites/default/files/La\%20Econom\%C3\% ADa\%20Digital\%20clave\%20para\%20el\%20crecimiento.pdf. [17/03/13]

[25] Imhoff., C. (2013). Converging Technologies: Real-Time Business Intelligence and Big Data [Online]. Intelligent Solution, Inc. Available: http://www.vitria.com/pdf/WP-Extending-Data-WarehouseArchitecture.pdf?submissionGuid=6a4c4eac-fe3b-4f16-bf4e$4 \mathrm{fd} 4 \mathrm{a} 208 \mathrm{e} 98 \mathrm{e} .[01 / 10 / 13]$

[26] Ferraté T. (2013). The Near Future of Robotics: Cloud Robotics [Online]. Portal Web de Robotica Educativa y Personal. Available: http://www.robotica-personal.es/2013/04/the-near-future-of-roboticscloud.html. [30/09/13]

[27] Ericsson. (2010a). Operator Revenue Growth [Online]. Ericsson Chanel. Available: http://www.youtube.com/watch?v=SKhb2cyDdLU. [12/12/12]

[28] Ericsson. (2012a). Thinking Cities Networked Society [Online]. Ericsson Chanel. Available: http://www.youtube.com/watch?v=6ctxP6Dp8Bk. [12/12/12]

[29] Corningin. (2012). A Day Made of Glass 2: Unpacked. The Story Behind Corning's Vision [Online]. Corningin Corporated Channel. Available: http://www.youtube.com/watch?v=X-GXO_urMow. [13/12/12]

[30] Ferraté T. (2012). Cloud Robotics New Paradigm is Near [Online]. Portal Web de Robotica Educativa y Personal. Available: http://www.robotica-personal.es/2013/01/cloud-robotics-new-paradigmis-near.html. [30/09/13]

[31] Flor Nancy Díaz Piraquive, Víctor Hugo Medina García, Rubén González Crespo (2014). ICT as a Means of Generating Knowledge for Project Management. Springer Proceedings in Complexity, pp. 617-629, ISBN: 978-94-007-7286-1, DOI: 10.1007/978-94-007-7287-8_50

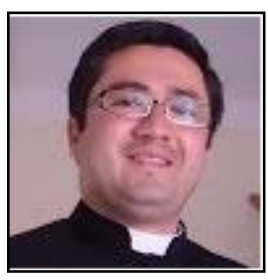

Juan Carlos Piedra Calderón received his Advance Study Diploma (DEA) part of doctorate program and received his Master degree in Business Process Management and Master in Information and Knowledge Management from Universidad Pontificia de Salamanca (UPSAM Spain). Actually is full time working on his doctoral thesis for $\mathrm{PhD}$ degree in Information and Knowledge Society program. He had worked as a Knowledge Management Expert in several projects. (UPSAM). Av/ de la Merced 108, 37005, Salamanca, España. Email: juankpc@ gmail.com

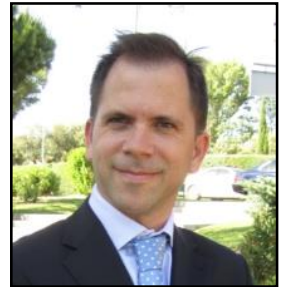

J. Javier Rainer received a PhD in Robotic and Automation from Universidad Politécnica de Madrid (UPM - Spain). He is working at the department of Languages and Computer Systems. Director of research and engineer investigation area in Bureau Veritas Centro Universitario and researcher in Intelligent Control group of UPM. Member of IARIA Cognitive technical committee. Paseo Juan XXIII, 3 - 28040 Madrid. España. Email: javier.rainer@gmail.com 